an impressive list of published material by the staffbut they point out that the present grant-in-aid is only sufficient to maintain the Museum as a relatively static organization. In such circumstances, progress is difficult, and the fact is emphasized that, in common with other museums, a relatively small increase in the annual grant would enable the institution to act as an efficient and educational centre. The importance of the policy of collecting material is stressed, and it is satisfactory to note the result of two geological expeditions in the field lasting for several weeks.

\section{Translations of Russian Scientific Literature}

IN a written answer to a question in the House of Commons on April 1, Mr. H. Nicholls, Parliamentary Secretary to the Ministry of Works, as representing the Lord President of the Council, said that the Department of Scientific and Industrial Research is at present purchasing copies of most translations of Russian scientific literature produced in the United States. Discussions are in progress between the Department and the National Science Foundation with a view of improving the present arrangements for the interchange of translations.

\section{Leeds University Library}

The annual report of the Librarian, University of Leeds, for the session 1956-57 (pp. 12. Leeds: The Brotherton Library, The University, 1957) records holdings of 412,809 and 170,006 pamphlets on June 30,1957 , of which 293,962 volumes and 113,833 pamphlets are in the Brotherton Library. Accessions during the year totalled 12,369 volumes, 3,325 pamphlets and 26,951 periodical parts ; 49,363 slips and cards were added to the catalogues, 4,872 books were sent to the binder, and of 97,924 loans to readers, 62,195 were by the Brotherton Library, 16,182 by the Institute of Education and 11,806 by the Medical Library. Reviewing the quinquennium, it is pointed out that only the steady increase of the book fund has enabled the Library to maintain the standard of the 1947-52 quinquennium for purchases of books and periodicals, but increase in senior staff was precluded, cataloguing and classification decreased and binding was restricted to eurrent and urgent needs. The use of the Library, particularly of the main library where the pressure on seating is concentrated, is the subject of special inquiry by the Nuffield Foundation.

\section{Indian Scientific Documentation Centre}

The annual report for 1956-57 of the Indian National Scientific Documentation Centre (New Delhi : National Physical Laboratory of India, 1957) records a further increase in the demand for the Centre's services. Copies of 4,305 scientific papers were supplied during the year, compared with 3,939 in $1955-56$, and of these 27,806 pages were in photocopy and 102,290 as microfilm : 33.5 per cent were from libraries in Delhi and 13.8 per cent from libraries elsewhere in India. Translations of 701 articles were also requested, as compared with 570 in 1955-56, and 637 were completed, chiefly from German (252), French (132) and Russian (101). 120 bibliographies wөге compiled, representing 230 pages compared with 147 in 1955-56 : 110 requests for bibliographies were received. With the holdings of the National Physical Laboratory library, the Centre's library now contains more than 26,000 volumes, and about 1,200 scientific publications are currently received. The list of current scientific literature is issued twice-monthly. The Centre also issues the "Bibliography of Scientific Publications of South and South-East Asia" and the Annals of Library Science, and maintains a master index of the translations carried out in the Commonwealth, notified through the British Commonwealth Scientific Organization.

\section{Forty Years of Soviet Science}

The Russian popular science monthly Priroda of November 1957 is devoted to the fortieth anniversary of the Soviet regime. It contains 15 articles concerned with the progress of science and technology during the past forty years. Three of these articles are of a general nature, the others discuss advances made in the study of fundamental particles and the atomic nucleus, semi-conductors, geology, chemistry, mathematics, astronomy, agriculture, geography, while the last four articles are devoted to the progress of seience in Kazakhstan, Latvia, the industry of the Urals and on the Soviet expedition in the Antarctic.

\section{International Journal of Health Education}

IN 1951 the International Union for Health Education was founded as non-governmental organization designed to contribute to the development of health education throughout the world. It has already arranged important international conferences, the last one, which met in Rome during May 1956, attracting 1,500 participants from more than fifty countries. The Union has now launched a journal, the first issue of which reflects its inter. national character (International Journal of Health Education, 1, No. 1 (January 1958). Pp. 64. Annual subseription rate: 12 Swiss francs; 3 dollars. Geneva : International Journal of Health Education, 3 rue Viollier, 1958). Besides articles of a general character, there are accounts of health education developments in Japan, the U.S.S.R., Africe, Turkey and Eouador; details of recent books, films and other visual aids are also included.

\section{World Low Air Temperature Record}

A worLd record low air temperature $-102 \cdot 1^{\circ} \mathrm{F}$. was observed in the screen (2 m. height) at the United States Amundsen-Scott International Geophysical Year station at the South Pole at 2137 G.M.T. on September 18, 1957. The full report, given in the Monthly Weather Review, November 1957, p. 326, is as follows: Wind, $4 \mathrm{kt}$.; temperature: surface, $-103 \cdot 3^{\circ} \mathrm{F}$; $2 \mathrm{~m}$., $-102 \cdot 1^{\circ} \mathrm{F}$.; $5 \mathrm{~m}$., $-101 \cdot 0^{\circ} \mathrm{F}$.; $10 \mathrm{~m} .,-79 \cdot 5^{\circ} \mathrm{F}$. It will be seen that there was an intense inversion of more than $23^{\circ} \mathrm{F}$. between the surface and $10 \mathrm{~m}$. The previous world record was $-100 \cdot 4^{\circ} \mathrm{F}$. registered at the South Pole on May 11, 1957. The record which stood for many years was $-90^{\circ} \mathrm{F}$. at Verkhoyansk, north-east Siberia, on February 5 and 7, 1892.

\section{Life Insurance Medical Research Fund of Australia} and New Zealand

Thre Life Insurance Medical Research Fund of Australia and New Zealand, established by the Life Offices' Association for Australasia to promote and assist scientific and medical research, is offering grants-in-aid to non-profit institutions with basic facilities and qualified personnel for medical research to be used in support of a specific programme of investigation under the direction of a particular investigator. Both fundamental and clinical research projects in the field of cardiovascular function and 